\title{
DISTANCE EDUCATION FOR LAW STUDENTS IN THE ARAB WORLD: TRENDS AND ISSUES
}

\author{
Khaled Khalaf Abed Rabbo Aldrou ${ }^{1}$ \\ ${ }^{1}$ Assistant professor, Faculty of law, Jadara University, Irbid, Jordan, e-mail: aldrou1970@yahoo.com, \\ ORCID: https://orcid.org/0000-0001-7559-4403
}

\begin{abstract}
The purpose of this study is to show how e-learning is being developed in the Arab world and its relevance to the issues of general and higher education in the Arab countries. The study is based on the research materials conducted in Egypt, Saudi Arabia, Jordan, Algeria. Recognizing the existing realities in the world and expressing a positive attitude to distance learning, the authors of the works described in this review analyze the opportunities and benefits of distance education for law higher education in Arab countries. They mark the flexibility and convenience of distance learning, which allows geographically dispersed students and especially those who live in areas of military conflicts, continue their education, attend a course of lectures of a leading specialist in their professional field. Among the disadvantages of this form of education the authors drew attention to the lack of live communication between students and a lecturer, implementation of group projects, selectivity of students in relation to the asynchronous communication, low saturation of distance courses in terms of content and others. It is also about the barriers that arise during the development of this sphere of education: lack of strength of the infrastructure equipment, network connection speed, difficulty of preparation and development of educational programs for law students in their native language (Arabic) and others.

Keywords: distance learning, law students, Information and Computer Technology, distance learning benefits, problems in the practice of using ICT, barriers to the development of distance learning.
\end{abstract}

\section{JEL Classification: K33, I23}

Formulas: 0; fig.: 0; tabl.: 0; bibl.: 9

Introduction. Distance learning (DL) is a set of information technologies that ensure the delivery of the bulk of the material being studied, interactive interaction between law students and lecturers in the learning process, and providing law students with the opportunity to independently master the material being studied. Modern distance learning is based on the use of the following basic elements: distance courses, web pages and sites, e-mail, forums and blogs, chat and ICQ, tele and video conferencing, virtual classrooms.

Today, distance learning is firmly occupying its niche in the education market, and it is possible to clearly identify areas where it has confidently established itself as an alternative to traditional education. And for lecturers, this form is attractive in terms of self-education and advanced training. In the educational field, distance learning should continue to complement the traditional full-time learning option, and in most cases blended learning will remain the most appropriate, when some courses, depending on their specifics, are studied in a traditional way, while others are distance learning.

Literature review. DL for lecturers also have unique opportunities to improve their qualifications not only at their place of residence, but also in scientific centers of the country, the opportunity to exchange experience with colleagues from other regions through virtual methodological associations, and participate in virtual 
teleconferences. The opportunities are great, but the material and intellectual costs are significant [9. S. 8-9; 10, p. 65; 11, p. 5].

Aims. The purpose of this study is to show how e-learning is being developed in the Arab world and its relevance to the issues of general and higher education in the Arab countries.

Methods. The study is based on the research materials conducted in Egypt, Saudi Arabia, Jordan, Algeria. The research and practical experience of organizing and conducting distance learning requires study. What are the trends in the development of distance education in different countries of the world? What is the place of vocational education in the system of continuing education?

Results. This article will focus on the role of distance education for law students in the Arab world, which is going through a difficult political situation, and the information and computer technologies (ICT) used.

Attitude towards distance education in the Arab world. The development of information technologies and the expansion of the information environment makes it possible to develop different types of information services, such as: A world without documents, universities without walls, virtual laboratories, museums, libraries, including for the needs of education - a virtual environment for schools and universities, virtual classrooms [2. P. 234].

The need for distance education is linked to change in the field of science and technology and in the social sphere. There are educators to meet the challenges of our era, as distance education provides numerous and very important educational opportunities:

- meeting the growing demand of society for education in connection with population growth and the associated increase in the number of law students;

- striving for various forms of education;

- the need for new technologies to assimilate the rapidly accumulating new law knowledge;

- the need for professional mobility of workers in a developing society, in the development and retraining of personnel.

- search for types of education that require lower costs due to the increase in costs for traditional education;

- expanding ties with community life in the field of training and education;

- promoting the education and literacy of girls and adults in the Arab world [1. P. 2].

What are the benefits of distance learning?

- access, thanks to computer technology, to a variety of teaching aids, especially at home, to events (videoconferences, lectures, forums, etc.) via satellite or via video;

- global integration of new concepts and terminology;

- Strengthening peer interaction through collaborative learning;

- improving the quality of education;

- emphasis on the development of the learner's skills of thinking, asking questions, searching for answers; 
- flexibility in organizing their academic work in time (law students can choose a time convenient for them), individualization of the passage of educational material, the choice of a resource (video, work with e-mail, browsing the website, etc.);

- management of your own ways to better memorize the content of training;

- search, receipt and access to information at any time;

- independence from geographic and political boundaries in an era of political instability, insecurity and forced migration. As a result of the escalation of adverse events in the Arab world, many law students have been deprived of the opportunity to attend classes. And here the role of e-learning in overcoming these (limiting conditions of conventional education) factors significantly increases;

- expanding access to information and sources that are inaccessible in the traditional learning environment [5. P. 53-66].

Offering flexibility and convenience, distance learning allows geographically distant students and students living in areas of military conflict to continue their education. It also provides them with the opportunity to take two courses at the same time. In addition, students have the opportunity to attend a course of lectures by a leading expert in their professional field.

Compulsory lecture and class learners cannot take breaks when they feel fatigued, unlike distance learning learners, who can stop listening to lectures or watching videos. The material is always available, students control the pace of learning [9]. Recordings of video lectures from previous semesters can be used in the future. This can be a helpful option when the instructor is sick or on a business trip, or if the instructor thinks that the topic is covered well in the recorded lecture.

Distance education requires the lecturer to develop teaching methods appropriate to the changed learning environment. The lecturer needs to learn how to teach, and students need to learn how to learn using distance learning resources [8. P. 391-402].

On the other hand, in the context of distance learning, there are opportunities to expand interaction with law students, in particular, with those who are ashamed to ask questions in class. While remotely, they can overcome their difficulties in making contact.

Experts note that distance education helps to overcome the lack of knowledge required to meet the needs of society inherent in traditional education, as can be seen in the curriculum. Therefore, e-learning has become an integral part of the educational process, as it supports the continuity of education, especially in the special socio-political conditions faced by Arab societies are available to an almost infinite number of students [7. P. 48-54].

Discussion. At the same time, researchers and educators note some disadvantages of distance education:

1. Distance education contributes to the laziness of law students, the refusal of independent work, counting on the help of the online component as a kind of "crutch". The student thinks that if he does not attend the lecture, he can use the video on the Internet and watch it at a later time. As a result, students start to lag behind. This creates problems in mastering the educational material of the course, since the 
understanding of the subsequent material and concepts is conditioned by the knowledge of the previous topics.

2. In many forms of distance education there is no live communication between student and lecturer. Many educators believe that face-to-face contact and interaction between law students and lecturers is critical to learning. The lack of such personal communication makes it difficult for the lecturer to stimulate and motivate students to work. Law students may experience feelings of isolation and lack of support. Nonverbal communication, in particular body language and facial expressions, as well as verbal cues cannot be transmitted in distance learning. Often times, teachers can recognize students' facial expressions in class as they understand them. Such "reading" is not possible in distance courses.

3. Group projects can be more difficult for distance students, it is more difficult for them to negotiate, they cannot learn from each other. In the absence of group interaction, they receive less satisfaction from the work.

4. Asynchronous communication has different effects on the self-awareness of law students. They do not allow the expression of emotions and the use of "body language". This turns out to be beneficial for shy students. They prefer an e-learning environment. Conversely, those who like to speak up and participate in discussions of traditional learning are more likely to avoid writing or participating in asynchronous electronic discussions [5. P. 66-75].

5. But Patrick J. Fahy believes that peer-to-peer interaction through existing online contacts (mediated communication) can be a more effective means of student support. Obvious advances in communication technologies that connect "voice and image" for interaction of lecturers and students in synchronous e-learning should be introduced [6].

6. Distance learning courses are poorly saturated in terms of content when instructors deliberately or subconsciously seek to avoid the additional complications associated with the distance learning environment. This jeopardizes the quality of teaching.

7. Distance learning courses require more diligence and preparation than traditional courses. Lectures must be clear [4]. Instructors often underestimate the time and resources required to develop course materials. Email volume for distance students often increases dramatically for instructors and assistants.

8. Institutions are often not well equipped to organize distance courses, in particular they do not have sufficient delivery methods for teaching materials to ensure effective learning. Faculty members are limited due to budgetary constraints in funding access to resources for solving distance learning problems.

9. Distance education faces challenges of academic integrity when evaluating student work. It can be difficult to determine the degree of a student's independence in performing a particular task.

Barriers to e-learning. E-learning faces the same barriers as any modern education system. Some of them: 
- The need to ensure the durability of infrastructure devices, the speed of the network connection, the participation of highly qualified specialists in ensuring the operation of the devices.

- The difficulty of preparing and developing educational programs in the native language for students (Arabic). Often the program is presented in English, which is frustrating for non-proficient students.

- Not all lecturers and students know how to use computers and the Internet, do not know how to interact in this environment. Parents of students may not be sufficiently aware of e-learning. This is especially true for the female part of the students.

- Educational sites are exposed to hacker attacks, hindering the educational process.

- Serious problems arise with funding or financial support for the creation of educational sites and equipping universities and schools with computers and Internet networks. To this should be added the costs of operation, maintenance and the cost of creating educational content in Arabic [2. P. 131-133].

Conclusion. The purpose of this study was to show how e-learning is developing in the countries of the Arab world, the relevance of its problems for general and higher education in Arab countries using the example of teaching in virtual classrooms. We believe that the application of such training ideally helps to solve modern educational problems. It is necessary to keep up with the progress in the field of modern technologies and develop. These technologies have invaded our Arab societies, whether we like it or not. This technical intrusion into the educational process requires empowering faculty and students to take advantage of it and use it in education. It should be noted that the Arab world is fully aware of the scale of changes that modern education is undergoing in connection with the use of ICTs and electronic devices, and seeks to use the possibilities of distance education, which make it possible to overcome in this particular situation the unfavorable circumstances of confrontation, the arena of which is the Middle East.

\section{References:}

1. Al-Mahdi, Suzan Mohammed. Distance education and its Hopefully role in educational institutions / research presented scientific Annual Sixteenth Congress, distance education in the Arab world, the Egyptian Society for Education and comparison, education mechanism in Boor Said, Suez Canal University, Egypt, 2008.

URL: https://kenanaonline.com/files/0100/100245/201\%ةنصول20\%نتراضئ.pdf (date of application: 4.11.2021).

2. Al-Mousa, Abdullah bin Abdul Aziz, Al-Mobarak, Ahmed bin Abdul Aziz. E-learning principles and application, Riyadh: Humaidhi Press, 2005.

3. Bakhti, Ibrahim. Virtual learning Teaching and Research Center. URL: http://bbekhti.online.fr/trv_pdf/EAD.pdf (дата обращения: 19.03.2021).

4. Bruce J.C., Bond S.T., Jones M.E. Teaching epidemiology and statistics by distance learning // Statistics in Medicine. 2002. Vol. 21. P. 1009-1020.

5. Darwish Ehab. E-learning, features, justified, requirements, potentials. Dar Al-Sahab, Cairo, 2009.

6. Fahy Patrick, J. Indicators of support in online interaction // International Review of Research in Open and Distance Learning. Vol. 4, No. 1, 2003. URL: http://www.irrodl.org/contact/v5/n1/fahy.html.

7. Katz, Y.J., Yablon, Y.B. Online university learning: Cognitive and affective perspectives. // Campus Wide Infor- mation Systems, 2003. 20 (2).

8. Speed, F.M., \& Hardin, H. Teaching statistics via distance: Duplicating the classroom experience // Communications in Statistics: Simulation and Computation, 2001, 30 (2).

9. Stephenson, R.W. Statistics at a distance // Journal of Statistics Education, 9 (3), 2001. URL: http:// www.amstat.org/publications/jse/v9n3/stephenson.html (date of application: 15.04.2021). 